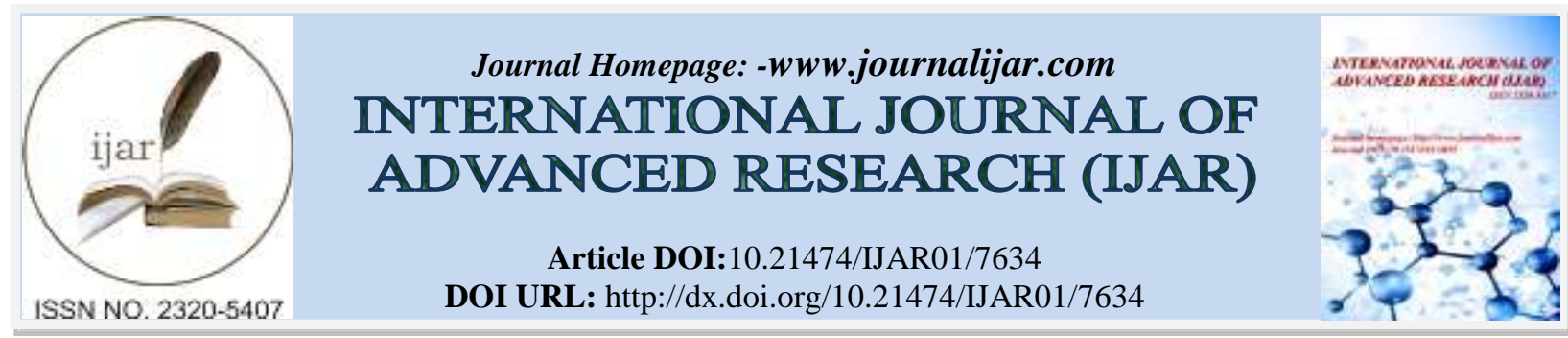

RESEARCH ARTICLE

\title{
GUCHAKARANJA (QUASSIA INDICA (GAERTN) NOOTEBOOM) -AN OVERVIEW.
}

\author{
Meghna $^{1}$, Dr. V V Shincymol ${ }^{2}$ and Dr. P Y Ansary ${ }^{3}$.
}

1. PG Scholar, Dept. of Dravyaguna vijnanam, Govt. Ayurveda College, Tripunithura.

2. Associate Professor, Dept. of Dravyaguna vijnanam, Govt Ayurveda College, Tripunithura.

3. Professor \& HOD, Dept. of Dravyaguna vijnanam, Govt. Ayurveda College, Tripunithura.

\section{Manuscript Info}

Manuscript History

Received: 24 June 2018

Final Accepted: 26 July 2018

Published: August 2018

Keywords:-

Guchakaranja, Raja Nighantu, Nighantu

Ratnakara, Karinjotta.

\section{Abstract}

Ayurvedic health care system mainly based on plant and plant based products. Plants have been the primary basis for drug discoveries and developing new drugs. The drug Guchakaranja is mentioned as one of the Karanja variety by Raja Nighantu and Nighantu Ratnakara. The mentioning of this drug is not found in any of the other classical Ayurvedic text books. It is popularly known as Karinjotta in Kerala. The drug Karinjotta had been mentioned in Van Reed's Hortus Malabaricus along with its medicinal uses. Its leaves are used in cold, fever $\&$ erysipelas. The oil prepared from fruit cures cholera $\&$ diseases of joints. The drug had been used extensively in folklore practice for many diseases like skin diseases, inflammatory disorders, fever, cough,joint disorders etc. Here the present review study is an attempt to provide reported detail information of this herb from various Ayurvedic textbooks,morphology and its study in modern area like its phytoconstituents and pharmacological actions.

Copy Right, IJAR, 2018,. All rights reserved.

\section{Introduction:-}

Ayurvedic health care system mainly based on plant and plant based products.Plants have been the primary basis for drug discoveries and developing new drugs. Some dravyas which are mentioned in Ayurvedic Nighantus are still unknown and there are not using the main stream clinical practices. Also folklore system of medicine is a rich source of knowledge which gives excellent unfailing remedies for a number of clinical conditions.

The present drug Guchakaranja is botanically correlated as Quassia indica Gaertn (Samadera indica Gaertn) belonging to the family Simaroubaceae commonly known as Niepa bark tree. The Ayurvedic reference of the drug can be seen in Raja Nighantu and Nighantu Ratnakara, in these Nighantus the drug is indicated for vata rogas ,visha, kandu, kushta, vicharchika and twak doshas ${ }^{[1,2]}$. The reference from Hortus Malabaricus text covering the medicinal drugs available $\&$ practiced in Kerala in the $17^{\text {th }}$ century.revealed its usage in inflammatory conditions, fever, skin diseases and rheumatic complaints ${ }^{[3]}$. The drug is popularly known as 'Karinjotta' in Kerala. . As the time passed many drugs used earlier are now out of the main stream clinical scenario.But the drug had been used extensively in folklore practices. 


\section{Nirukti Of Guchakaranja}

The etymology of the word Guchakaranja had explained in Sabdakalpadruma as a bush or a bundle of bunch of flowers $^{[4]}$. In Sanskrit-English dictionary by Monier and Williams the meaning of the word Guchakaranja explained as a variety of Karanja which is a shrub having bunch of flowers or cluster of blossoms. ${ }^{[5]}$

Classification in texts ${ }^{[1,2]}$

Ra.Ni- Prabhadradi Varga

Ni. Ra- Prathama Khanda- Gudoochyadi varga

\section{Synonyms mentioned in Ra.Ni}

- Snigdha dala :

leaves are smooth \& glabrous

- Gucha pushpaka :

flowers are seen in bundle/bunches

- Nandi

- Matrunandi

- Sanandi

- Vasava

that brings happiness

- Dhantadhawana

twigs are useful for dantadavana

Rasapanchaka \& Doshakarma Analysis ${ }^{[1],[2]}$

Table 1:-Rasapanchaka \& Doshakarma Analysis of Guchakaranja

\begin{tabular}{|l|l|l|}
\hline & Ra.Ni & Ni.Ra \\
\hline Rasa & Katu, Tikta & Katu ,Tikta \\
\hline Guna & & \\
\hline Virya & Ushna & Ushna \\
\hline Vipaka & & \\
\hline Doshakarma & Vatahara & Vatahara \\
\hline
\end{tabular}

Therapeutic indications: ${ }^{[1],[2]}$

- Visha

- Vicharchika

- Vata vikaras

- Kushta

- Twak rogas

- Arshas

Parts used $^{[3]}$ :

Seeds, Stem bark, and leaves

\section{Aamayika prayoga}

- The use of its leaves in cold, fever, erysipales is mentioned.

- The oil prepared from fruit cures cholera \& diseases of joints

\section{Botanicalidentity}

The drug Karinjotta had been botanically correlated to Quassia indica Gaertn in CRC World dictionary of Medicinal plants, Encyclopedia of World Medicinal plants, Indian Materia Medica by A.K.Natkarni,Indian Medicinal Plants by Krithikar \& Basu and in Flora of Presidency of Madras. In the presently available Hortus Malabaricus translated by K.S. Manilal, he had also mentioned the Botanical source of Karinjotta as Samadera indica Gaertn. In Indian Medicinal Plants published by Kottakal Aryavaidya Sala and the 'Medicinal plants of Aryavaidyasala' the drug Karinjotta had been correlated to Guchakaranja and botanically to Samadera indica Gaertn

Botanical source: Quassia indica (Gaertn) Nooteboom or

Samadera indica Gaertn

Family:Simaroubaceae 


\section{Vernacular Names ${ }^{[10]}$}

English - Bitter wood, Madagascar Quassia, Niepa bark tree

Hindi - Lokhandi

Kannada -Nipa Samadera, Kaduhonge

Malayalam -Karinjotta

Malaysian -Manuggal

Marathi- Lokhandi

Sanskrit -Guchakaranja

Sinhalese : Samadera

Spanish -Simaruba de Madagascar

Tamil -Karincottai

Telugu -Lokanti

Taxonomy ${ }^{[11]}$

Distribution and Habitat:

Wastelands in the plains. Generally the plant is distributed along backwaters \& moist deciduous forest

Habit: $^{[12],[13]}$

Niepa Bark Tree is an evergreen tree or shrub up to $10 \mathrm{~m}$ tall

\section{Stem:}

bark is pale and transversely cracked. Wood is light yellow and soft.

\section{Leaves:}

Leaves are elliptic-oblong, somewhat pointed-rounded at base, pointed to tapering at tip, leathery, hairless, shining, net veined, acute to acuminate at apex, coriaceous, glabrous, shining, reticulately nerved. Petioles $1-2 \mathrm{~cm}$ long,stout.

\section{Inflorescence:}

Terminal or axillary pseudo-umbel

\section{Flowers:}

Flowers are 20 or more in umbel-like hairless or finely velvet-hairy clusters. Bisexual, Flower-cluster-stalks are 7-30 $\mathrm{cm}$ long, stout, flat, thick-above; Flower-stalks are 1-1.5 cm long

\section{Fruit:}

1-4 together, flat, smooth, glandular and net veined, to $3 \mathrm{~cm}$ in fruit, jointed at base; bracts minute.

\section{Seeds:}

thin testa, absent endosperm, plano-convex cotyledons, measuring upto $3.5 \mathrm{~cm} \times 2.5 \mathrm{~cm}$, large.

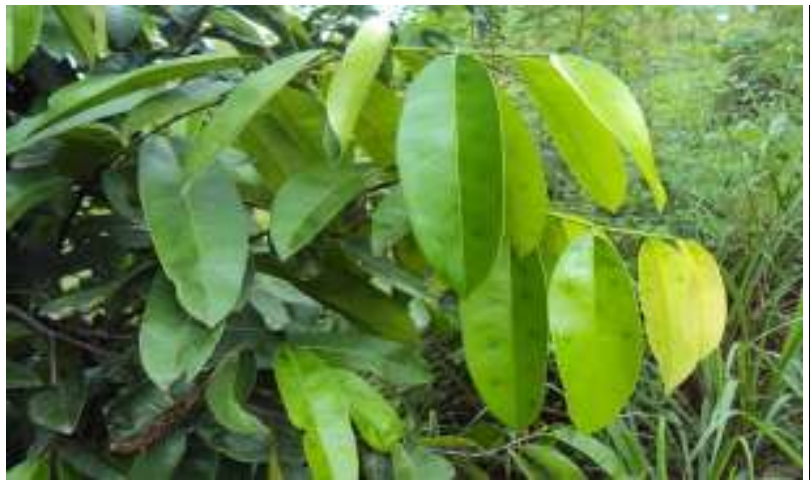

Figure 1: Leaves of Guchakaranja

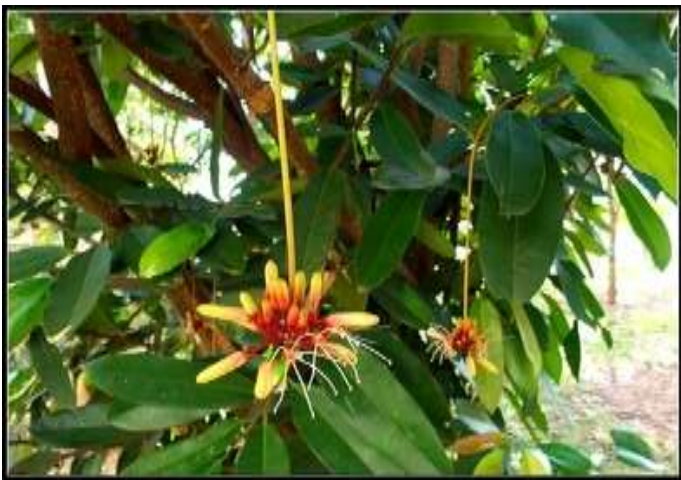

Figure 2: Flower of Guchakaranja

Taxonomical classification ${ }^{[14]}$

Quassia indica (Gaertn) Nooteboom 
Botanical name: Quassia indica (Gaertn ) Nooteboom

Kingdom: Plantae, Plants

Subkingdom: Tracheophyta Vascular plants

Super division:Spermatophyta Seedplants

Division: Magnoliophyta Floweringplants

Class: Magnoliopsida- Dicotyledons

Sub-class: Sapindales

Family: Simaroubaceae

Genus: Quassia

Species: Quassia indica (Gaertn) Nooteboom

\section{ChemicalConstituents ${ }^{[15]}$}

Fixed oil, 33\%; with triolein $87.7 \%$, triplamitin, $8.41 \%$, tristearin 3.89\%, an alkaloid, a bitter principle and a glycoside, samaderin. The wood contains a bitter principle similar to quassin.

Study on stems yielded four new quassinoids named samaderines X (1), Y (2), and Z (3), and indaquassin X (5), and a new C19 quassinoid glycoside, 2-O-glucosylsamaderine C (10), together with five known quassinoids, samaderines B (7), C (8), and E (4), indaquassin C (6), and simarinolide (9). Study of the seeds and bark yielded four quassinoids: indaquassin C, samaderins C, B and A.

Folkloric Uses ${ }^{[15]}$

1. Mixture of the powdered bark or wood scrapings in warm water or coconut oil is used for fever.

2. For rheumatism, seed is roasted, pounded, and applied over affected area.

3. Leaves are bruised and applied over skin eruptions.

4. Bath with leaves is indicated for women during puerperal period.

5. Juice from pounded bark also used for skin diseases.

6. Oil extracted from fruit kernels used for rheumatism.

7. Leaf decoction used to relieve cough.

8. Seeds worn around the neck for asthma prevention.

9. Seeds used as emetic and purgative.

\section{A Traditional Taila preparation}

The vaidyas of Pathanamthitta district in Kerala prepares Pindataila with certain modifications ,for enhancing its therapeutic effects. They usually modify Pindataila by adding Nimba taila(neem oil),Erandataila(castor oil),Guchakaranja taila ,Ingudi taila and Varaha vasa/gogritha. It is known locally as Mukkottu preparation.. In this modified Pinda taila seed oil of Guchakaranja is taken. It is mainly indicated in Kapha-vata samana, sulahara and sophaghna. It is indicated in twak-mamsa asritha uthana Vatarakta and also used in Diabetic Neuropathic conditions.

\section{Pharacological Studies \\ Anti-inflammatory activity Invitro - study $^{[16]}$ :}

Study evaluated the anti-inflammatory activity of Samadera indica by HRBC membrane stabilization. The antiinflammatory activity of the crude ethanol extract, aqueous extract of leaves part of Samadera indica were compared to that of the standard drug diclofenac. The extract in concentration of $250-1000 \mu \mathrm{g} / \mathrm{ml}$ showed a dose dependent inhibition of haemolysis of erythrocyte induced by hypotonic solution. The ethanolic extract of Samadera indica showed significant anti-inflammatory activity in comparison to aqueous extract and with standard drug diclofenac. The percentage protection of lysis for standard diclofenac $50 \mathrm{mcg} / \mathrm{ml}$ is $73 \%$, ethyl alcohol extract at a concentration of $1000 \mu \mathrm{g} / \mathrm{ml}$ is $67 \%$ and aqueous extract is $50 \%$. The present investigation suggests that the membrane stabilizing activity of Samadera indica may be playing a significant role in its anti-inflammatory activity.

In -vivo study ${ }^{[17]}$ :

Study of a methanol extract of Quassia indica leaves in Wistar albino rats showed significant in-vitro antioxidant activity by DPPH radical scavenging method and significant anti-inflammatory activity against carrageenan induced paw edema. 


\begin{abstract}
Antimicrobial Topical Herbal Formulations: ${ }^{[18]}$
In vitro:

Study evaluated the toxicity of a methanolic extract of Samadera indica Gaertn. and its suitability for use in herbal formulations. The in-vitro antimicrobial study of the formulated ointment showed significantly strong activity against S. aureus, P. aeurginosa and C. albicans. Results suggest the formulated ointment and gel are safe and efficient formulations for topical delivery.
\end{abstract}

\title{
Antibacterial and antioxidant activity of Polyherbal Antiseptic Ointment: ${ }^{[19]}$ \\ In vitro :
}

An ointment, formulated using methanolic extracts of Azaridachta indica, Chromolaena odorata, Mimosa pudica, and Samadera indica, was evaluated for antibacterial and antioxidant activity. Results showed concentrationdependent increase in scavenging activity, the effect attributed to flavanoids and tannins. Antibacterial testing showed wound healing activity. Overall study showed an effective polyherbal antiseptic ointment.

\section{Antioxidant ${ }^{[20]}$}

\section{In vitro:}

The antioxidant activity of methanol extract of leaves of Samadera indica.Methanol extract of Samadera indica was tested for in vitro free radical scavenging assays. Samadera indica extract effectively scavenged free radicals at all different concentrations and showed its potent antioxidant activity in different models.

\section{Hepatoprotective of Leaves: ${ }^{[21]}$ \\ In vivo:}

Study evaluated the potential hepatoprotective effect of methanolic extract of Quassia indica leaves in carbon tetrachloride induced liver injury in Wistar albino rats. The methanolic extract of Quassia indica was given for fourteen days and compared with serum biochemical parameters and histopathological evaluation with the standard silymarin treated group.Results showed hepatoprotective activity with restoration of increased level of serum biochemical markers and normalization of Hepatic globular architecture.

\section{Antihelmintic: ${ }^{\text {[2] }}$}

\section{In vitro:}

Study of alcoholic and aqueous extracts from leaves were evaluated for antihelmintic activity against Rallietina spiralis and Ascaridia galli. The three concentration ( $10,25,50 \mathrm{mg} / \mathrm{ml})$ of each extracts were studied for determination of time of paralysis and time of death of the worm. Piperazine citrate was included as standard reference and distilled water as control. The extracts showed significant dose dependent antihelmintic activity

Antifeedant: ${ }^{[23]}$

In vitro:

Study of the seeds and bark of Samadera indica yielded four quassinoids: indaquassin C, samaderins C, B and A. Indaquassin $\mathrm{C}$ was the most effective antifeedant. Samaderins C Increased pupal duration and induced pupal mortality.

\section{Toxic pathology: ${ }^{[24]}$}

In vivo :

Study evaluated the toxicopathology effect of Quassia stem extract fractionation of various extracts on mice liver and kidney at $100 \mathrm{mg} \mathrm{kbw}$. Q. indica chloroform extract has the lowest level of damage to hepatocytes while hexane fraction caused the least damage in kidney tubular epithelium. The ethyl acetate showed the most epithelial damage

\section{Anti-arthritic activity: ${ }^{[25]}$}

In vivo study:

Three plants namely Naravalia zeylanica, Strobilanthus ciliates and Samadera indica were selected for the phytochemical analysis and invivo screening of anti-arthritic studies. Male Wistar rats weighing between 150$200 \mathrm{gm}$ were selected for the experiment. They were grouped in a group of six animals each in to five group. The ethanolic \& aqueous extracts of drugs were used for the study. The ethanolic \& aqueous extracts of Samadera indica leaves showed stasticially significant result in reducing inflammation on day $14^{\text {th }}$ and $21^{\text {st }}$ day. 


\section{Conclusion:-}

Hence it can be concluded that the drug Guchakaranja mentioned in Nighantus having the properties of passifying inflammatory conditions, skin disorders and arthritic conditions. The rasa panchakas mentioned in Nighantus substantiate its clinical uses. Research works have proved its various pharmacological activities like antiinflammatory, anti-arthritic ,anti oxidant, anti spasmodic, anti microbial, anti helminthic, antiviral, anti feedant and growth regulating.So it can be stated that the drug Guchakaranja is a wonderful drug with multidirectional action.

\section{References:-}

1. Narahari. Rajanighantu of pandit Narahari. Tripathi I, editor. Varanasi: Chowkhamba Krishnadas Academy; $277 \mathrm{p}$.

2. Shastri DGR. Nighant Ratnakar:Part I. Patel BA shastri TKSMAVV, editor. Bombay: Vishnu Vasudev Godbole; 1867. 102 p.

3. Manilal K S. Hortus Malabaricus. Kerala University,Thiruvananthapuram,6 :p.61-63,2008.

4. Deva RK. Shabda kalpadrum :[An Encyclopedic Dictionary of Sanskrit Words arranged in alphabetical order giving the etymological origin of the words according to Panini] Volume 2. Varanasi: Chaukhambha Sanskrit Series office; 1967. 333page p.

5. Monnier \& Williams, Sanskrit English dictionary, vol 1,Parimal publications 2008 p 524

6. Basu BD. Indian Medicinal Plants:Vol.1. 2nd editio. Dehradun: Inter National Book Distributors; 2008. 507$508 \mathrm{p}$.

7. Gamble JS. Flora of the Presidency of Madras. 2nd reprin. Dunn, S. T; Fischer CEC, editor. Delhi: Neeraj Publishing House; 2016. 163 p.

8. Warrier PK. Indian Medicinal Plants: A Compendium of 500 Species. Hyderabad: Universities Press; 2010. Volume 5; 55-56.

9. Udayan PS. Medicinal Plants of Arya Vaidya Sala Herb Garden. Balachandran I, editor. Kottakkal: Arya Vaidya sala; 2009. 298 p.

10. Manungal, Philippine Herbal medicines Bitter wood, Quassia indica www.stuartxchange.org/Manunggal.html

11. Nadkarni AK , Nadkarni KM. Indian materia medica, bombay. Popular Prakasan, 1:p.9-10, 1096

12. Basu BD. Indian Medicinal Plants:Vol.1. 2nd editio. Dehradun: Inter National Book Distributors; 2008. 506 p.

13. Umberto Quattrocchi. CRC World Dictionary of Medicinal and PoisonousPlants. CRC Press, p.45:2012.

14. Biodiversity Documentation for Kerala Part 6: Flowering Plants, N. Sasidharan, Flora of Maharastra State Dicotyledones, Vol I, Lakshminarasimhan P. \& Prasanna P. V, 2000

15. Manunggal, Philippine Medicinal Plants; details of Quassia indica Gaertn, www.stuartxchange.org/Manunggal.html

16. Anti-inflammatory activity of Samadera indica leaves by membrane stabilization ; G.R. Rajalakshmi and Jyoti Harindran ; International Journal of Pharmaceutical Science and Research 2013;4(2):721-3

17. Jolly John, Suraj.S, Abdul Vahab A, Dr Jyoti Harindran, S.E Godwin, Anti-inflammatory Effect of Quassia indica leaf extract And Role of Antioxidant activity; ISSN: 2319-5622; Journal of Pharma Research 2014, 3(2) 11-13

18. P.H.Rajasree, Vidya Vishwanad, Merin Cherian JE and RS. Formulation and evaluation of antiseptic polyherbal ointment. Int J Pharm LIFE Sci. 2012;3(2):1475-89.

19. Anusha P SBR. Phytochemical profile and antimicrobial potential of methanolic extracts of bark and leaf of Quassia indica ( Gaertn .) Nooteb . 2017;6(5):269-76.

20. Viswanad V, Aleykutty NA, Zacharia SM, Thomas L. Evaluation of Antioxidant and Free Radical Scavenging Activity of Samadera indica Using In vitro Models. Pharmacogn J [Internet]. 2011;3(23):85-90.

21. John J. Potential Hepatoprotective Effect Of Methanolic Extract Of Quassia Indica Leaves. Int J Institutional Pharm Life Sci. 2015;4(March-April):102-8

22. Deepa, P R C, Bhat R. Phytochemical properties and antimicrobial activities of leaf, bark, fruit extracts and silver nanoparticles of Samadera indica Gaertner. Eur J Biotechnol Biosci [Internet].

23. Harindran Jyoti, Rajalakshmi G.R. ,In vitro Antihelminthic activity of Samadera indica; Research Journal of Pharmacy and Technology, 2011, Vol 4, No 1015; 3(12):30-7

24. Termites control without chemicals,HDRA, the organic organisation. Page 12-14

25. Dr. Francis Mathew and Christy K. Jose M. Screening of phytochemical and biological properties of selected plants used for the treatment of arthritis. 2017. p. 1-25. 